\title{
PERILAKU MINUM OBAT PADA PASIEN DIABETES MELLITUS (DM) TPE 2 DI RUANG JANGER RSD MANGUSADA BADUNG
}

\author{
Drug-taking Behavior in Type 2 Diabetes Mellitus (DM) Patients in The Janger \\ Room of RSD Mangusada Badung
}

I Wayan Artana

S1 Keperawatan, STIKES Bina Usada Bali, Indonesia

Korespondensi: I Wayan Artana dan wayan.artana473@gmail.com

\begin{abstract}
ABSTRAK
Latar Belakang: Penyakit diabetes mellitus (DM) merupakan suatu penyakit tidak menular (PTM) yang jumlahnya meningkat cukup signifikan, menghabiskan biaya pengobatan yang tinggi, dan penderita seumur hidupnya harus meakai obat. Dengan demikian, penanganannya memerlukan suatu ketaatan perilaku penderita untuk meminum obat. Tujuan Penelitian: Untuk mengerti dan memahami perilaku minum obat pasien DM tipe 2 di ruang Janger RSD Mangusada Badung. Metedologi: Jenis penelitian kualitatif dengan metode fenomenologi, proses analisis data menggunakan mode Miles dan Haberman, serta alat analisis datanya menggunakan teori sosial focus norm theori. Hasil: Ditemukan bahwa ketidaktaatan pasien minum obat di rumahnya sebelum dirawat diakibatkan beberapa faktor di antaranya obatnya habis, keluhan-keluhan penyakitnya sudah tidak timbul lagi, lupa, atau malas mencari obatnya. Sedangkan ketaatan pasien minum obat di ruang Janger RSD Mangusada didasari oleh beberapa alasan di antaranya adalah kerutinan perawat memberikan obat dan menekankan pentingnya minum obat, adanya perilaku meniru semangat dan ketaatan dari pasien lain untuk minum obat, serta adanya keinginan dari dalam diri untuk cepat sembuh.
\end{abstract}

Kata Kunci: Perilaku; Minum Obat; Diabetes Mellitus

ABSTRACT
Background: Diabetes mellitus (DM) is a non-communicable disease (NCD) whose number has increased significantly, has high medical costs, and patients have to use drugs for the rest of their life. Thus, the treatment requires an obedient behavior of the patient to take the drug. Research Objectives: The research was conducted in the Janger room of RSD Mangusada Badung which aims to understand and understand the drug-taking behavior of type 2 DM patients. Methodology: The type of research is qualitative with phenomenological methods, the data analysis process uses Miles and Haberman modes, and the data analysis tool uses social theory focus norm theory Result: In this study, it was found that the patient's disobedience to taking medication at his home before being treated was caused by several factors, including the drugs running out, complaints of the disease no longer occurring, forgetting, or being lazy to look for the medicine. Meanwhile, the patient's adherence to taking medicine in the Janger room at the Mangusada Hospital is based on several reasons, including the nurse's routine of giving medicine and emphasizing the importance of taking 
medicine, the behavior of imitating the spirit and obedience of other patients to take medicine, and the desire from within to recover quickly.

Keywords: Behavior; Take Medicine; Diabetes Mellitus

\section{PENDAHULUAN}

Penyakit diabetes mellitus (DM) merupakan satu penyakit tidak menular (PTM) yang jumlahnya meningkat cukup signifikan. Perjalanan penyakit ini untuk menjadi kronis sangat besar, karena sampai saat ini belum ada obat yang pasti dapat menyembuhkannya (Kemenkes RI, 2013). Ketaatan penderita minum obat merupakan satu kunci baginya untuk mempertahankan gula darahnya tetap berada dalam batas-batas normal, karenanya mereka meminum obat seumur hidupnya. Perilaku taat ini sangat memengaruhi mereka di dalam menjaga kualitas hidup, melawan penyakit DM.

\section{International Diabetes}

Federation (IDF) memprediksi adanya kenaikan jumlah penyandang DM di Indonesia dari 9,1 juta pada tahun 2014 menjadi 14,1 juta pada tahun 2035 (Perkeni, 2015). Secara realitias prevalensi DM di Indonesia pada penduduk umur $\geq 15$ tahun pada 2013 sebesar 1,5\%. Akan tetapi, jumlah ini meningkat menjadi 2,0\% di tahun 2018. Provinsi Bali juga mengalami hal yang sama yaitu terjadi peningkatan prevalensi DM dari $1,3 \%$ di tahun 2013 menjadi $1,7 \%$ di tahun 2018. DKI Jakarta menduduki tempat teratas dalam prevalensi DM di tahun 2013 dan 2018 yaitu $2,5 \%$ dan $3,4 \%$, sedangkan NTT menempati ranking terbawah dengan prevalensi DM di tahun 2013 0,8\% meningkat menjadi $1,2 \%$ di tahun 2018 . Secara rata-rata seluruh provinsi di Indonesia mengalami peningkatan prevalensi DM (Kemenkes RI, 2018). Kematian maternal dan neonatal hingga saat ini di Indonesia selalu menjadi topik utama. Kematian bagi neonatal dapat terjadi setiap tiga menit dan setiap satu jam pada satu perempuan. Kematian ini berhubungan dengan kehamilan, persalinan ataupun masa nifas (UNICEF, 2012). Berdasarkan hasil diagram dari SDKI bahwa angka kematian ibu di Indonesia pada tahun 2012 AKI meningkat menjadi 359 per 100.000 kelahiran hidup dan pada tahun 2015 AKI kembali turun menjadi 305 per 100.000 kelahiran hidup (BPS, 2017).

\section{TUJUAN PENELITIAN}

Tujuan dari penelitian ini adalah Mengerti dan memahami perilaku minum obat pasien DM tipe 2 di ruang oleg RSD Mangusada Badung.

\section{METODE PENELITIAN}

Penelitian ini adalah kualitatif yaitu penelitian yang berupaya menganalisis kehidupan sosial dengan cara menggambarkan dunia sosial dari sudut pandang atau interpretasi individu (informan) dalam latar alamiah. Dengan kata lain penelitian kualitatif berupaya menjelaskan bagaimana seorang individu melihat, menggambarkan, atau memaknai dunia sosialnya yang merupakan hasil dari interaksi sosialnya (Nanang Martono, 2015). Paradigma yang digunakan adalah interpretatif, yaitu suatu penelitian 
yang memandang realitas sosial sebagai sesuatu yang holistic atau utuh, kompleks, dinamis, penuh makna, dan hubungan gejala interaktif (reciprocal) (Nanang Martono, 2015); (Artana, 2019)

\section{HASIL PENELITIAN}

Pengumpulan data penelitian dilakukan dengan wawancara mendalam, observasi proses (situasi, perilaku tenaga kesehatan, analisis dokumen), dan analisis dokumen yang tersedia. Semua proses berkaitan dengan apa yang dikehendaki untuk diteliti. Penggunaa berbagai macam cara tersebut memberikan keabsahan data yang dapat dipertanggungjawabkan hasilnya. Dengan demikian, hasil penelitian akan benar-benar memberikan suatu realitas apa yang sedang terjadi pada komunitas atau masyarakat yang sedang diteliti. Beberapa pertanyaan yang diajukan secara mendalam kepada informan memunculkan berbagai pendapat tentang ketaatan mereka minum obat. Selain itu observasi akan prosesproses tingkah laku tenaga kesehatan juga direkam. Hasil dari wawancara, observasi ditriangulasikan dengan analisisdokumen. Cara-cara tersebut menghasilkan suatu data yang benarbenar dapat memberikan situasi dan gambaran utuh tentang perilaku minum obat pasien DM di ruang oleg RSD Mangusada Badung. Jika mengacu kepada tujuan penelitian, jawaban-jawaban informan, hasil observasi, dan analisis dokumen bila ditelusuri lebih teliti ada beberapa tema besar yang muncul di antaranya.

\section{PEMBAHASAN}

Penyakit DM terjadi karena ketidakseimbangan kadar gula darah di dalam tubuh. Jumlah yang tersedia lebih banyak dari kemampuan tubuh untuk mengolahnya, sehingga berlebihan ada di dalam darah. Kemampuan tubuh untuk mengolah bisa juga terjadi karena kekurangan atau tidak tersedianya suatu zat hormon insulin. Hormon yang ditugaskan untuk mengolah gula itu bisa jumlahnya menurun atau fungsinya yang tidak optimal (Askandar Tjokroprawiro, Poernomo Boedi Setiawan, Chairul Effendi, 2015).

Adanya gula berlebih di dalam tubuh bila berlangsung lama dapat menimbulkan efek samping kepada berbagai sistem organ di antaranya sistem organ kardiovaskuler menimbulkan stroke, penyakit jantung, kesemutan, dan luka-luka di daerah kaki. Pada sistem pencernaan bisa mengakibatkan penyakit liver, lambung, dan usus (Jawapos.29 Desember, 2016).

Perawatan DM memerlukan suatu ketekunan dalam malakukan diet, teratur minum obat, dan melakukan olah raga secara rutin dan terukur. Minum obat teratur merupakan kunci untuk menjaga agar gula darah tetap optimal. Dikatakan demikian, karena makanan yang masuk ke dalam tubuh pasti mengandung suatu karbohidrat yang di dalam tubuh dirubah menjadi gula. Begitu juga bila melakukan suatu aktifitas berlebihan, tubuh akan membentuk gula sendiri dengan cara mengubah protein atau lemak menjadi gula dengan bantuan hormon glucagon. Perilaku minum obat yang teratur semestinya dilakukan oleh penderita DM. akan tetapi, tidak semua dari mereka mau melakukannya dengan berbagai alasan. 


\section{Perilaku Pasien DM Minum Obat di Rumah}

Perilaku merupakan suatu reaksi seseorang yang langsung terlihat atau yang tidak tampak (Pieter \& Lubis, 2012). Dalam hal ini perilaku ditimbulkan oleh adanya suatu stimulus internal ataupun eksterna yang diproses melalui kognitif, afektif, dan motorik. Dengan demikian, perilaku diekspresikan oleh tubuh fisik atau tubuh emosi (perasaan) akibat adanya suatu rangsangan (stressor) dari dalam atau luar diri.

Dikaitkan dengan perilaku minum obat pasien DM, penyakit yang diderita merupakan suatu stimulus yang mengakibatkan pasien minum obat. Penyakit DM ini akan terus menyerang tubuh dan pasti menimbulkan suatu kerusakan. Pasien seharusnya juga rutin minum obat karena mereka terus menerus dirangsang oleh penyakitnya. Hal demikian telah dilakukan oleh beberapa pasien DM yang dirawat di ruang oleg RSD Mangusada seperti yang disampaiakn oleh.

Informan NB, 65 tahun seorang laki-laki beralamat di..........yang kesehariannya tinggal di rumah membersihkan halaman, menyapu, dll, karena sudah pensiun sebagai Aparatur Sipil Negara di Dinas Pertanian Badung. Saat wawancara dilakukan ada dikatakan.

Saya sudah tujuh tahun menderita kencing manis. Saat masih aktif bekerja penyakit ini belum muncul dan setelah 10 tahunnya pensiun saya menerima penyakit yang tidak menyenangkan. Akan tetapi, saya sudah rutin minum obat yang diberikan oleh dokter. Saya selain disuntik insulin juga minum tablet vitamin tiga kali sehari.

\section{Alasan-alasan Pasien DM Taat Minum Obat Saat dirawat di Ruang Oleg RSD Mangusada}

Berbicara tentang alasanalasan, sebenarnya membicarakan dasar/bukti (keterangan) yang dipakai untuk menguatkan pendapat. Di samping itu, alasan juga dapat menjadi pendorong (untuk berbuat, memilih) dan dapat dijadikan sebagai pembenar tindakan (perbuatan). Collin dalam Wirawan (2015:134) dan Wahyu (2016:5) menyatakan bahwa untuk mendapatkan hakikat kebenaran harus mampu berpikir lebih dalam lagi melampaui fenomena yang tampak hingga mendapatkan 'meaningfulness', yaitu memengaruhi orang lain untuk bertindak.

$\begin{array}{cc}\text { Dalam bertindak } & \text { seseorang } \\ \text { tidak } & \text { hanya }\end{array}$ melaksanakannya, tetapi juga menempatkan diri dalam berpikir dan berperilaku orang lain. Artinya, alasan-alasan ataupun motivasi tertentu yang mendasari tindakannya. Mengetahui alasan-alasan/tindakan berarti tahu tentang fenomena secara mendalam, yaitu mampu memahami makna di balik tindakan tersebut. Hal ini berarti bahwa pola pikir penilaian terhadap suatu fenomena berangkat dari subjektivisme, yang tidak hanya memandang dari suatu gejala yang tampak, tetapi juga berusaha menggali makna di balik gejala tersebut. Dalam hal ini fenomenologi tidak pernah berusaha mencari pendapat informan apakah hal ini benar atau salah, tetapi berusaha untuk mereduksi kesadaran informan dalam memahami fenomena tersebut.

Artinya, mengapa mereka melakukannya dengan mempertimbangkan kondisi sosial, ekonomi, budaya, dan norma etika agama yang dimilikinya. Setelah itu 
dia melakukan tindakan hingga mendapatkan insentif (tujuannya). Pada keadaan ini subjek dan obyek merupakan dua hal yang saling berhubungan, bukan dua hal yang terpisahkan. Berdasarkan gambaran tersebut, di bawah ini dianalisis beberapa alasan yang mendasari penderita DM di ruang oleh RSD Mangusada Badung taat minum obat di antaranya

\section{KESIMPULAN}

Dari hasil penelitian dan pembahasan yang telah dilakukan dengan berbagai teori sosial, dapat dirangkum suatu simpulan di antaranya.

Sebelum dirawat di ruang Oleg RSD Mangusada Badung pasien-pasien DM cara minum obatnya di rumah tidak teratur. Artinya, kerutinan mereka meminum obat tidak baik, tidak sesuai dengan anjuran dokter yang merawat, atau malas menyediakan obat bagi dirinya.

Ketidaktaatan pasien minum obat di rumahnya sebelum dirawat diakibatkan berbagai faktor di antaranya obatnya habis, keluhankeluhan penyakitnya sudah tidak timbul lagi, lupa, atau malas mencari obat. Ada berbagai alasan yang mengakibatkan pasien DM di ruang Oleg RSD Mangusada minum obat secara teratur, seperti kerutinan perawat memberikan obat dan menekankan pentingnya minum obat, keinginan pasien untuk sembuh dari luka-luka kaki yang di deritanya, dan adanya sikap meniru dari pasien terhadap pasien lainnya yang dengan semangat minum obat.

\section{DAFTAR PUSTAKA}

Aminah B dan Amir. (2014). Praktik Relasi Wacana dan Kuasa
Foucaltdian dalam Relasi Multi Profesi di Indonesia. Jurnal Populis Volume 8, Nomor 1 Maret 2014.

Artana, I. (2019). Ideologi Bhakti Yoga di Pasraman Sri Sri Radha Rasesvara Sibang Gede. Denpasar:Pascasarjana Universitas Hindu Indonesia.

Askandar Tjokroprawiro, Poernomo Boedi Setiawan, Chairul Effendi, et al. (2015). Buku Ajar Ilmu Penyakit Dalam. (Vol. 2, pp. 1-7). Fakultas Kedokteran Universitas Airlangga Rumah Sakit Pendidikan Dr.Soetomo Surabaya.

Chaidir, Reny, et all. (2017). Hubungan Self Care dengan Kualitas Hidup Pasien Diabetes Mellitus.

Jawapos.29 Desember. (2016). 9 Penyakit Katastropik Bikin Beban Negara Bengkak Rp 1,69 Triliun. https://www.jawapos.com/fea tures/humaniora/29/12/2016/ 9-penyakit-katastropik-bikinbeban-negara-bengkak.

Kahirani, M. (2016). Psikologi Umum . Yogyakarta: Aswaja Pressindo.

Kemenkes RI. (1971). SK Menteri Kesehatan RI No. 25/Kab/B.VII/71.

Kemenkes RI. (2013). Riskesdas 2013. In National Report 2013. https://doi.org/1 Desember 2013

Kemenkes RI. (2018). Riskesdas 2018. In Riset Kesehatan Dasar 2018.

Khairanai., M. (2016). Psikologi Umum. Yogyakarta: 2016.

Mohebi, Siamak, et all. (2018). Ralationship Between Perceived Social Support and 
Self care Bahavior in Type 2

Diabetica: Across Sectional

Study. http://www.jehp.net

Nanang Martono. (2015). Metode

Penelitian Sosial. Konsep-

Konsep Kunci. Depok: PT.

Raja Grapindo Persada.

Ningtyas, Dwi Wahyu, et all.

(2013). Analisis Kualitas

Hidup Pasien DM 2 di RSUD

Bangil, Pasuruan, Jawa

Timur. Repository Unej. http://repository.unej.ac.id

Perkeni. (2015). Konsensus

Pengelolaan dan Pencegahan

DM 2 di Indonesia. Jakarta, Perkeni.

Pieter, H. Z., \& Lubis, N. L. (2012).

Pengantar Psikologi dalam

Keperawatan. In Pengantar

Psikologi dalam Keperawatan

(pp. xiv-168). Jakarta:

Kencana Prenada Media

Group.

Pitaloka, Ardiningtiyas, D. (2017).

Teori-teori Psikologi Sosial

Kontemporer. Jakarta: PT

Raja Garfindo Persada.

Rembang, Vini Paskalini, et all. (2017). Hubungan Dukungan Sosial dan Motivasi pada DM

2 di Poliklinik Penyakit

Dalam RSUD Mokopido

Toli-Toli. E-Journal Unsrat. http://ejournal.unsrat.ac.id

Sarwono, S. W. (2017). Teori-Teori
Psikologi Sosial. In PT. Rajagrafindo Persada (Issue December 2007). Jakarta, PT. Raja Grafindo Persada

Siobhan, O'neil \& David, E. (2018). Social,Pshychological and Health Needs of Type II Diabetes: A Focus Group Study of The Western Health Board. http://hdl.handle.net

Suastika, K. (2011). Tanya-Jawab Seputar Obesitas dan Diabetes.

Sudarma., M. (2016). Sosiologi untuk Kesehatan. Jakarta: Salemba Medika.

Sutopo, H. (2012). Metodologi Penelitian Kualitatif. Dasar Teori dan Terapannya dalam Penelitian (p. 254). Surakarta: Sebelas Maret University Pres.

Yanti, Meidika Wulan \& Wahyuni, C. U. (2017). Hubungan Dukungan keluarga dengan Kualitas Hidup DM Tipe 2 di Puskesmas Pademawu. Journal Unair, 5. http://ejpurnal.unair.ac.id

Yudianto, Kurniawan, et all. (2008). Kualitas Hidup Penderita Diabetes Mellitus di RSUD Cianjur. Jurnal Unpad, 10. http://jurnal.unpad.ac.id 